\title{
Should degenerative horizontal tear of the medial meniscus be treated with surgery?
}

\author{
Medial menisküsün dejeneratif horizontal yırtığı cerrahi ile mi tedavi edilmelidir?
}

\author{
O. Şahap Atik (iD), MD \\ Professor of Orthopedic Surgery, Turkish Joint Diseases Foundation, Ankara, Turkey
}

Arthroscopic partial meniscectomy of degenerative meniscal tear is one of the most commonly performed orthopedic procedures around the world. However, reliable evidence shows only short term benefit of arthroscopic partial meniscectomy over placebo or non-surgical treatment in patients with degenerative meniscal tears.

In the long-term, patients who undergo knee arthroscopy versus those who receive conservative management do not have more benefits in terms of pain or function..$^{[1,2]}$

There were no significant difference between arthroscopic meniscectomy and nonoperative management with strengthening exercises in terms of relief in knee pain, improved knee function, or increased satisfaction in patients after two years of follow-up. ${ }^{[1]}$

In the intention-to-treat analysis, they did not find significant differences between the study groups in functional improvement six months after randomization; however, $30 \%$ of the patients who were assigned to physical therapy alone underwent surgery within six months. ${ }^{[2]}$

Studies on the effect of arthroscopic partial meniscectomy in individuals with degenerative meniscal tears have shown similar improvements in pain and function as in individuals who underwent sham surgery. ${ }^{[3,4]}$

Systematic reviews and meta-analyses have similarly reported no extra benefit of arthroscopic partial meniscectomy or debridement in addition to exercise for individuals with degenerative meniscal tears. ${ }^{[5,6]}$

Furthermore, arthroscopic procedures are reported to be associated with adverse events, including venous thromboembolism and even pulmonary embolism and death. ${ }^{[7]}$ The incidence of venous thromboembolism was higher in patients who were 50 years of age or older, and the incidence in female patients was higher if they had been prescribed oral contraceptive medication..$^{[7]}$

In conclusion, the balance between the advantages and disadvantages weighs heavily on the choice of treatment; conservative or surgical. ${ }^{[8]}$

\section{REFERENCES}

1. Yim JH, Seon JK, Song EK, Choi JI, Kim MC, Lee KB, et al. A comparative study of meniscectomy and nonoperative treatment for degenerative horizontal tears of the medial meniscus. Am J Sports Med 2013;41:1565-70.

2. Katz JN, Brophy RH, Chaisson CE, de Chaves L, Cole BJ, Dahm DL, et al. Surgery versus physical therapy for a meniscal tear and osteoarthritis. N Engl J Med 2013;368:1675-84.

3. Moseley JB, O'Malley K, Petersen NJ, Menke TJ, Brody BA, Kuykendall DH, et al. A controlled trial of arthroscopic surgery for osteoarthritis of the knee. N Engl J Med 2002;347:81-8.

4. Sihvonen R, Paavola M, Malmivaara A, Itälä A, Joukainen A, Nurmi H, et al. Arthroscopic partial meniscectomy versus sham surgery for a degenerative meniscal tear. N Engl J Med 2013;369:2515-24.

5. Thorlund JB, Juhl CB, Roos EM, Lohmander LS. Arthroscopic surgery for degenerative knee: systematic review and meta-analysis of benefits and harms. Br J Sports Med 2015;49:1229-35. 
6. Brignardello-Petersen R, Guyatt GH, Buchbinder R, Poolman RW, Schandelmaier S, Chang Y, et al. Knee arthroscopy versus conservative management in patients with degenerative knee disease: a systematic review. BMJ Open 2017;7:e016114.
7. Maletis GB, Inacio MC, Reynolds S, Funahashi TT. Incidence of symptomatic venous thromboembolism after elective knee arthroscopy. J Bone Joint Surg [Am] 2012;94:714-20.

8. Atik OŞ. Do we surgeons perform surgery only? Eklem Hastalik Cerrahisi 2016;27:123-4. 